\title{
Effect of different levels of sodium sesquicarbonate on in vitro rumen fermentation parameters
}

\author{
Hunny Sharma', Veena Mani ${ }^{1}$, Sachin Kumar ${ }^{1}$, Srobana Sarkar ${ }^{2}$ and Hujaz Tariq ${ }^{3}$
}

Received: 05 February 2020 / Accepted: 31 March 2020 / Published online: 12 July 2020

(C) Indian Dairy Association (India) 2020

\begin{abstract}
This experiment was conducted to study the effects of sodium sesquicarbonate on in vitro rumen fermentation parameters. Sodium sesquicarbonate $(\mathrm{NaSc})$ was added at different levels $(0.5,1,1.5,2,2.5$ and $3 \%)$ to the substrates having concentrate: roughage ratio (concentrate: sugargraze fodder) of 50:50 and 60:40. There was no significant effect of addition of sodium sesquicarbonate (upto $3 \%$ ) on in vitro DM digestibility and organic matter digestibility in different treatments. Average value of $\mathrm{NH}_{3}-\mathrm{N}$, IVFA, MBP, PF, molar proportion of acetate, propionate and butyrate also remained unaffected due to $\mathrm{NaSc}$ supplementation.
\end{abstract}

Keywords: Buffer, In vitro, Rumen fermentation, Sodium sesquicarbonate

\section{Introduction}

There is decline in milk yield in many dairy herds which appear to be temporarily increased by overfeeding of grains (Kmicikewyez and Heinrichs, 2014; Abdela, 2016) and such diets may potentially exacerbate subacute acidosis which represents one of the most important metabolic disorders that affects rumen fermentation resulting in decrease in DMI, milk yield, and milk fat content, animal welfare and farm profitability (Morgante et al. 2007; Mao et al. 2017). Such rations also tend to support less rumination which reduces the production of salivary bicarbonate. Subacute ruminal acidosis is characterized by low ruminal $\mathrm{pH}(5.8-5.0)$ and

\footnotetext{
${ }^{1}$ Animal Nutrition Division, National Dairy Research Institute, Karnal, 132 001, Haryana, India

${ }^{2}$ Animal Nutrition Division, Central Sheep and Wool Research Institute, Avikanagar, 304 501, Rajasthan, India

${ }^{3}$ De Heus India, Rajpura, 140 401, Punjab, India
}

Hunny Sharma $(\square)$

Animal Nutrition Division

National Dairy Research Institute, Karnal, 132 001, Haryana, India Email: vet657@gmail.com; Tel: +91-9149964783 an alteration in ruminal biohydrogenation of dietary polyunsaturated fatty acids (Bauman and Griinari, 2003; Plaizier et al. 2008).

Different approaches have been made for improving the ruminant production by searching the alternatives for stabilizing the rumen $\mathrm{pH}$ to minimize the occurrence of rumen acidosis and related disorders (Owens and Basalan, 2016). Rumen buffer could be one such alternative considering facts that addition of dietary buffers to control rumen $\mathrm{pH}$ can be justified if bunk management and nutritional factors cause low pH (Kang and Wanapat, 2013). Buffers can neutralize the excessive acidity due to increased production of volatile fatty acids but the effects depend upon type of buffer, dose and type of animal in which it is supplemented (Sen et al. 2006). Bicarbonates are commonly used as exogenous buffer as their dissociation constant ( $\mathrm{pka}=6.25$ ) is close to normal rumen $\mathrm{pH}$ thus possessing high acid consuming capacity (Marden et al. 2008) and thus prevent further depression in $\mathrm{pH}$ (Humer et al. 2018). Sodium bicarbonate increases rumen $\mathrm{pH}$, produces a more desirable rumen fermentation and increases rumen fluid outflow. Dietary supplementation of sodium sesquicarbonate could be one of the alternative as it is a mixture of sodium bicarbonate and sodium carbonate and is naturally occuring an alkalizing agent. The $\mathrm{pH}$ of a one percent sodium sesquicarbonate solution is 9.9 as compared to sodium bicarbonate which is 8.4 thus expected to have better potential for buffering action besides being cost effective. Therefore, the present experiment was conducted to study the effects of sodium sesquicarbonate on in vitro rumen fermentation parameters.

\section{Materials and Methods}

\section{Substrate composition, treatments and parameters estimated}

Sugargraze (moderately draught tolerant sweet sorghum hybrid) fodder and concentrate mixture were dried in hot air oven at $60^{\circ} \mathrm{C}$ for $48 \mathrm{~h}$ and ground using a hammer mill to pass thtrough $1 \mathrm{~mm}$ sieve. The substrate was prepared by mixing concentrate mixture and sugargraze fodder in the ratio of 50:50 and 60:40. Sodium sesquicarbonate was added in treatment groups at different levels viz. $0.5,1.0,1.5,2.0,2.5$ and $3.0 \%$ of substrate whereas the control group comprised of only substrate. Proximate principles and fibre 
fractions of the concentrate mixture and the substrate were determined according to AOAC (2005) and Van Soest et al. (1991). Rumen fluid and particulate matter were collected from the goats $(n=4)$ with the help of stomach tube in the morning before feeding (sugargraze and concentrate in 70:30 ratio) and watering of animals, in a pre-warmed thermo flask. The incubations were carried out as described by Menke and Steingass (1988) to study in vitro gas production. Three sets of in vitro trials in triplicates were conducted to estimate the effect of addition of different levels of sodium sesquicarbonate in diet/substrate on the various parametrs such as IVGPT, partition factor, $\mathrm{pH}$ and microbial protein synthesis along with in vitro DM/OM degradability to obtain a complete picture for rumen fermentation pattern.

\section{Analytical procedure}

The substrate (sugargraze and concentrate; $200 \mathrm{mg}$ ) was weighed and placed into the bottom of the $100 \mathrm{~mL}$ graduated glass syringes without sticking it to the sides of syringe. The medium mixture solution and rumen liquor were mixed in the ratio $2: 1$ and immediately after thorough mixing, $30 \mathrm{~mL}$ of this incubation medium was injected to glass syringes (Haberle, Germany) using an auto dispenser. The level of piston was recorded (initial reading) and the syringes were placed in the incubator preadjusted at $39 \pm 0.5^{\circ} \mathrm{C}$ for $24 \mathrm{~h}$. After the completion of incubation period, total gas production was calculate after correcting corresponding blank values and $\mathrm{pH}$ of syringe contents was estimated with the help of digital $\mathrm{pH}$ meter (Model: $\mathrm{pH}$ Spear, Eutech Instruments, Malaysia). The contents of the syringe were then emptied into centrifuge tubes and centrifuged at $3000 \mathrm{rpm}$ for 15 min till clear supernatant was obtained which was then preserved at $-20^{\circ} \mathrm{C}$ for the estinamtion of individual volatile fatty acids (Erwin et al. 1961) using gas chromatograph (Nucon 5700, Nucon Engineers, New Delhi) equipped with flame ionization detector and stainless steel column packed with chromosorb 101 mesh 80 - 100 (length 1.5 m; o.d 3.175 mm; i.d. 2 mm). An aliquot of supernatant was acidified with equal volume of $0.5 \mathrm{M}$ $\mathrm{HCl}$ and kept at $-20^{\circ} \mathrm{C}$ for estimation of ammonia nitrogen by Kjeldahl method. True DM and OM digestibility of samples were estimated as per method described by Van Soest et al. (1991). The pellet left after centrifugation was refluxed in beakers with neutral detergent solution for $1 \mathrm{~h}$ and thereafter, contents were filtered through the sintered glass crucible (G-1) washed with hot water and kept in hot air oven at $100^{\circ} \mathrm{C}$ for drying. In vitro true dry matter digestibility IVTDMD was calculated as the difference between the weights of the DM incubated and the $\mathrm{DM}$ residue left. The residue in each crucible was ashed in muffle furnace at $550^{\circ} \mathrm{C}$ for $2 \mathrm{~h}$ to determine the in vitro true organic matter digestibility (IVTOMD). The partitioning factor (PF) and microbial biomass production (MBP) were calaculated with the help of equations based on parameters like IVTDMD, IVTOMD, total gas and net gas volume (Blummel et al. 1997; Blummel and Lebzien, 2001).

\section{Equations}

$\mathrm{PF}=\underline{\text { In vitro true } \mathrm{DM} \text { digested }(\mathrm{mg})}$

Total gas produced $(\mathrm{mL})$

$\operatorname{MBP}(\mathrm{mg})=\mathrm{TDOM}(\mathrm{mg})-($ Net gas volume $\times 2.20)$

\section{Statistical analysis}

The statistical analysis of the data was done using one-way analysis of variance (ANOVA) by SPSS, 2010 version 16.

\section{Results and Discussion}

Detailed chemical composition of the feed ingredients and the substrate prepared from them has been given in Table 1. The same substrate was used in both the control and treatment groups. The effect of different levels of sodium sesquicarbonate in 50C: $50 \mathrm{R}$ and $60 \mathrm{C}: 40 \mathrm{R}$ ration in vitro digestibility, $\mathrm{pH}$, net gas production, $\mathrm{PF}$ and MBP is presented in Table 2 and IVFA and $\mathrm{NH}_{3}$ in Table 3. In the present study, the mean value of $\mathrm{pH}$ in 60C:40R was found to be significantly $(\mathrm{P}<0.001)$ higher than 50C: $50 \mathrm{R}$ and there was no effect of buffer addition on $\mathrm{pH}$ value. Similarly, net gas production, IVDMD and IVOMD were also higher in the diet with 60C:40R composition. Diet with 50C:50R had higher values of MBP, PF and higher proportion of acetate ; and lower in propionate. However, there was no difference in the levels of $\mathrm{NH}_{3}$ and butyrate concentrations between the two diets. Hence, supplementation of sodium sesquicarbonate ( 0.5 upto $3 \%$ ) and the interaction between diet and treatment had no effect on rumen fermentation parameters. The findings of the present study are consistent with those of Xu et al. (1994) who reported that supplementation of rumen buffers in lactating Holstein cows ( $1.5 \%$ and $2.2 \%$ of DMI) and observed no change in rumen fluid

Table 1 Chemical composition (\% DM basis) of the substrate

\begin{tabular}{llc}
\hline Attribute & Sugargraze fodder & Concentrate mixture \\
\hline DM & 28.00 & 89.56 \\
CP & 10.20 & 19.53 \\
EE & 1.29 & 3.74 \\
Ash & 8.64 & 11.22 \\
ADF & 37.29 & 12.38 \\
NDF & 58.65 & 26.37 \\
NDICP & 5.30 & 1.94 \\
ADICP & 1.14 & 0.69 \\
Hemicellulose & 21.40 & 13.99 \\
Cellulose & 21.00 & 6.40 \\
ADL & 7.75 & 2.32 \\
CHO & 79.87 & 65.51 \\
td NFC & 26.00 & 40.26 \\
td CP & 9.70 & 19.25 \\
td FA & 0.30 & 2.74 \\
td NDF & 24.8 & 13.13 \\
TDN & 54.10 & 71.81 \\
\hline
\end{tabular}


Table 2 Effect of different levels of sodium sesquicarbonate on in vitro digestibility, $\mathrm{pH}$, net gas production, IVFA, PF and MBP

\begin{tabular}{|c|c|c|c|c|c|c|c|c|c|c|c|c|c|}
\hline \multirow[t]{2}{*}{ Parameter } & \multirow[t]{2}{*}{ Substrate } & \multicolumn{7}{|c|}{ Level of supplementation (\%) } & \multicolumn{3}{|c|}{$\begin{array}{ll}\text { Mean } & \text { SEM }\end{array}$} & \multicolumn{2}{|c|}{$P$ value } \\
\hline & & 0 & 0.5 & 1 & 1.5 & 2 & 2.5 & 3 & & & $\mathrm{~S}$ & $\mathrm{~T}$ & $\mathrm{~S} * \mathrm{~T}$ \\
\hline \multirow[t]{3}{*}{$\overline{\mathrm{pH}}$} & $50 \mathrm{R}: 50 \mathrm{C}$ & 6.64 & 6.58 & 6.54 & 6.60 & 6.56 & 6.56 & 6.59 & $6.58^{\mathrm{a}}$ & 0.02 & $<0.001$ & 0.548 & 0.629 \\
\hline & $40 \mathrm{R}: 60 \mathrm{C}$ & 6.84 & 6.83 & 6.87 & 6.82 & 6.79 & 6.83 & 7.08 & $6.86^{\mathrm{b}}$ & 0.04 & & & \\
\hline & Mean & 6.74 & 6.71 & 6.71 & 6.72 & 6.67 & 6.69 & 6.83 & & & & & \\
\hline & $50 \mathrm{R}: 50 \mathrm{C}$ & 35.00 & 34.00 & 35.33 & 34.66 & 35.33 & 35.00 & 35.33 & $34.95^{\mathrm{a}}$ & 0.21 & $<0.001$ & 0.985 & 0.773 \\
\hline \multirow{2}{*}{$(\mathrm{mL} / 24 \mathrm{~h})$} & $40 \mathrm{R}: 60 \mathrm{C}$ & 39.33 & 40.00 & 39.33 & 39.67 & 39.67 & 39.00 & 39.50 & $39.50^{\mathrm{b}}$ & 0.26 & & & \\
\hline & Mean & 37.17 & 37.00 & 37.33 & 37.17 & 37.50 & 37.00 & 37.42 & & & & & \\
\hline IVDMD & $50 \mathrm{R}: 50 \mathrm{C}$ & 61.48 & 62.19 & 61.90 & 61.21 & 61.29 & 61.19 & 61.23 & $61.50^{\mathrm{a}}$ & 0.29 & $<0.001$ & 0.804 & 0.966 \\
\hline \multirow[t]{2}{*}{$(\%)$} & $40 \mathrm{R}: 60 \mathrm{C}$ & 65.07 & 65.81 & 66.80 & 66.10 & 65.49 & 65.18 & 65.84 & $65.76^{\mathrm{b}}$ & 0.27 & & & \\
\hline & Mean & 63.27 & 64.00 & 64.35 & 63.65 & 63.39 & 63.19 & 63.54 & & & & & \\
\hline IVOMD & $50 \mathrm{R}: 50 \mathrm{C}$ & 62.02 & 62.96 & 62.57 & 62.36 & 61.82 & 61.91 & 62.05 & $62.24^{\mathrm{a}}$ & 0.29 & $<0.001$ & 0.888 & 0.991 \\
\hline \multirow[t]{2}{*}{$(\%)$} & $40 \mathrm{R}: 60 \mathrm{C}$ & 65.93 & 66.71 & 67.38 & 66.89 & 66.81 & 66.40 & 66.45 & $66.65^{\mathrm{b}}$ & 0.28 & & & \\
\hline & Mean & 63.97 & 64.84 & 64.98 & 64.62 & 64.32 & 64.15 & 64.25 & & & & & \\
\hline \multirow[t]{3}{*}{$\mathrm{PF}$} & $50 \mathrm{R}: 50 \mathrm{C}$ & 3.36 & 3.49 & 3.37 & 3.41 & 3.31 & 3.34 & 3.33 & $3.37^{b}$ & 0.02 & $<0.001$ & 0.728 & 0.528 \\
\hline & $40 \mathrm{R}: 60 \mathrm{C}$ & 3.16 & 3.12 & 3.20 & 3.21 & 3.15 & 3.21 & 3.13 & $3.17^{\mathrm{a}}$ & 0.02 & & & \\
\hline & Mean & 3.27 & 3.31 & 3.28 & 3.31 & 3.23 & 3.28 & 3.23 & & & & & \\
\hline \multirow[t]{3}{*}{ MBP (mg) } & $50 \mathrm{R}: 50 \mathrm{C}$ & 38.98 & 42.42 & 39.48 & 40.11 & 37.56 & 38.28 & 38.29 & $39.31^{\mathrm{b}}$ & 0.63 & 0.005 & 0.766 & 0.696 \\
\hline & $40 \mathrm{R}: 60 \mathrm{C}$ & 35.91 & 34.98 & 37.46 & 37.70 & 35.61 & 37.32 & 34.78 & $36.25^{\mathrm{a}}$ & 0.68 & & & \\
\hline & Mean & 37.45 & 38.70 & 38.47 & 38.91 & 36.58 & 37.80 & 36.54 & & & & & \\
\hline
\end{tabular}

C: Concentrate mixture, R: Roughage, S: Substrate, T: Treatmnet

Table 3 Effect of different levels of sodium sesquicarbonate on in vitro ammonia and volatile fatty acid concentration

\begin{tabular}{|c|c|c|c|c|c|c|c|c|c|c|c|c|c|}
\hline \multirow[t]{2}{*}{ Parameter } & \multirow[t]{2}{*}{ Substrate } & \multicolumn{6}{|c|}{ Level of supplementation (\%) } & & \multirow[t]{2}{*}{ Mean } & \multirow[t]{2}{*}{ SEM } & \multicolumn{3}{|c|}{$P$ value } \\
\hline & & 0 & 0.5 & 1 & 1.5 & 2 & 2.5 & 3 & & & $\mathrm{~S}$ & $\mathrm{~T}$ & $\mathrm{~S} * \mathrm{~T}$ \\
\hline \multirow{3}{*}{$\begin{array}{l}\mathrm{NH}_{3}-\mathrm{N} \\
(\mathrm{mg} / \mathrm{dL})\end{array}$} & $50 \mathrm{R}: 50 \mathrm{C}$ & 9.71 & 9.89 & 9.52 & 9.24 & 9.52 & 9.52 & 9.33 & 9.53 & 0.12 & 0.404 & 0.833 & 0.658 \\
\hline & $40 \mathrm{R}: 60 \mathrm{C}$ & 9.15 & 9.80 & 9.05 & 10.08 & 9.98 & 10.55 & 9.80 & 9.77 & 0.23 & & & \\
\hline & Mean & 9.43 & 9.85 & 9.29 & 9.66 & 9.75 & 10.03 & 9.57 & & & & & \\
\hline \multirow{3}{*}{$\begin{array}{l}\text { Acetate } \\
(\mathrm{mM})\end{array}$} & $50 \mathrm{R}: 50 \mathrm{C}$ & 38.53 & 39.47 & 39.24 & 37.53 & 38.32 & 37.68 & 38.17 & $38.42^{\mathrm{b}}$ & 0.29 & $<0.001$ & 0.704 & 0.467 \\
\hline & 40 R:60 C & 34.22 & 33.33 & 35.88 & 34.86 & 36.47 & 35.81 & 33.36 & $34.85^{\mathrm{a}}$ & 0.52 & & & \\
\hline & Mean & 36.38 & 36.40 & 37.56 & 36.19 & 37.39 & 36.74 & 35.76 & & & & & \\
\hline \multirow{3}{*}{$\begin{array}{l}\text { Propionate } \\
(\mathrm{mM})\end{array}$} & $50 \mathrm{R}: 50 \mathrm{C}$ & 10.84 & 11.36 & 10.80 & 10.13 & 11.72 & 10.80 & 10.13 & $10.83^{\mathrm{a}}$ & 0.21 & $<0.001$ & 0.883 & 0.696 \\
\hline & $40 \mathrm{R}: 60 \mathrm{C}$ & 16.02 & 15.70 & 16.58 & 17.13 & 16.78 & 17.44 & 16.35 & $16.57^{\mathrm{b}}$ & 0.35 & & & \\
\hline & Mean & 13.43 & 13.53 & 13.69 & 13.63 & 14.25 & 14.12 & 13.24 & & & & & \\
\hline \multirow{3}{*}{$\begin{array}{l}\text { Butyrate } \\
(\mathrm{mM})\end{array}$} & $50 \mathrm{R}: 50 \mathrm{C}$ & 7.51 & 7.04 & 6.97 & 7.64 & 8.09 & 6.97 & 7.29 & 7.36 & 0.16 & 0.091 & 0.753 & 0.857 \\
\hline & 40 R:60 C & 7.01 & 6.68 & 7.12 & 6.41 & 7.20 & 6.82 & 7.00 & 6.89 & 0.18 & & & \\
\hline & Mean & 7.26 & 6.86 & 7.04 & 7.02 & 7.65 & 6.89 & 7.15 & & & & & \\
\hline
\end{tabular}

C: Concentrate mixture, R: Roughage, S: Substrate, T: Treatmnet

$\mathrm{pH}$ and VFA molar percentage. The results of this study are in accordance with those of Umucalilar and Seker (2000) who carried out an in vitro experiment with different ratios of $\mathrm{NaHCO}_{3}(0,0.5$, $1.0,1.5 \%)$ and $\mathrm{MgO}(0,0.25,0.5$ and 1$)$. They found that $\mathrm{NaHCO}_{3}$ supplementation had no effect on $\mathrm{pH}$, buffering capacity, TVFA and gas production but increased the levels of $\mathrm{NH}_{3}$ whereas $\mathrm{MgO}$ supplementation increased the values of $\mathrm{pH}$, buffering capacity, TVFA and gas production. However, results are in disagreement with Patra and Yu (2013) who reported an decrease in molar percentage of acetate and acetate-to-propionate ratio, whereas the molar percentage of propionate increased quadratically with increasing bicarbonate concentration. This difference could possibly be due to change in $\mathrm{pH}$ in the above study which varied from 6.0 to 6.38 in the above study which was not found in our study because of difference in both dose and souce of bicarbonate added. Furthermore, bicarbonate is regularly now a days being supplemented to dairy cattle rations to reduce incidences of acidosis and to counteract milk fat depression by increasing molar percentage of acetate and decreasing molar percentage of propionate (Cruywagen et al. 2015). Therefore, there has been a 
wide discrepancy in results of addition of buffers on comparison of in vitro and in vivo studies indicating that factors other than bicarbonate concentrations in media might also affect these results. In this study there was significant effect of incubation time on fermentation parameters. Our findings were also similar with those of Pereira and Armenanto (2000), Dschaak et al. (2010) and Bougouin et al. (2018) who observed no effect on digestibility supplementing $\mathrm{NaHCO}_{3}$ in the diet. Grant and Mertens (1992) studied the effect of buffer $\mathrm{pH}(5.2,6.2$ and 6.8) on in vitro digestion kinetics and observed that low $\mathrm{pH}$ decreased fiber digestion. Mao et al. (2017) found that sodium bicarbonate supplementation ( $7 \%$ of substrate) under in vitro condition increased the final $\mathrm{pH}$ levels and the concentration of total volatile fatty acids and the proportions of acetate, propionate and total branched chain VFA were also affected $(p<0.001)$ by incubation time $(\mathrm{p}<0.001)$ and interaction between incubation time and bicarbonate supplementation. They also found that total gas production was higher in the bicarbonate group but the concentration of $\mathrm{NH}_{3}-\mathrm{N}$ was almost similar among the control and bicarbonate supplemented group.

\section{Conclusion}

Addition of sodium sesquicarbonate upto $3 \%$ ) of substrate did not show any significant effect on in vitro rumen fermentation parameters.

\section{Aclnowledgements}

The authors thanks the Meera enterprises (Gujarat) and Director National Dairy Reasearch Institute (Karnal) for the financial support.

\section{References}

Abdela N (2016) Sub-acute ruminal acidosis (SARA) and its consequence in dairy cattle: A review of past and recent research at global prospective. Achiev. Life Sci 10: 187-196

AOAC (2005) Official Methods of Analysis, $18^{\text {th }}$ edition. Association of Official Analytical Chemists, Arlington, Verginia

Bauman DE, Griinari JM (2003) Nutritional regulation of milk fat synthesis. Annu Rev Nutr 23: 203-227

Blummel M, Lebzien P (2001) Predicting ruminal microbial efficiencies of dairy rations by in- vitro techniques. Livest Prod Sci 68: 107-117

Blummel M, Makkar HPS, Becker K (1997) In-vitro gas production: a technique revisited. J Anim Physiol Anim Nutr 77: 24-34

Bougouin A, Ferlay A, Doreau M, Martin C (2018) Effects of carbohydrate type or bicarbonate addition to grass silage-based diets on enteric methane emissions and milk fatty acid composition in dairy cows. J Dairy Sci 101: 6085-6097

Cruywagen CW, Taylor S, Beya MM, Calitz T (2015) The effect of buffering dairy cow diets with limestone, calcareous marine algae, or sodium bicarbonate on ruminal $\mathrm{pH}$ profiles, production responses, and rumen fermentation. J Dairy Sci 98: 5506-5514

Dschaak CM, Eun JS, Young AJ, Stott RD, Peterson S (2010) Effects of supplementation of natural zeolite on intake, digestion, ruminal fermentation, and lactational performance of dairy cows. Professional Animal Scientist 26: 647-654
Erwin ES, Marco GJ, Emery EM (1961) Volatile fatty acid analyses of blood and rumen fluid by gas chromatography J Dairy Sci 44: 17681771

Goering HK, VanSoest PJ (1970) Forage Fiber Analyses (apparatus, reagents, procedures and some applications). Agriculture Handbook No 379. ARS, USDA Washington DC

Grant RH, Mertens DR (1992) Influence of buffer $\mathrm{pH}$ and raw corn starch addition on in vitro fiber digestion kinetics. J Dairy Sci 75: 27622768

Humer E, Petri RM, Aschenbach JR, Bradford BJ, Penner GB, Tafaj M, Zebeli Q (2018) Invited review: Practical feeding management recommendations to mitigate the risk of subacute ruminal acidosis in dairy cattle. J Dairy Sci 101: 872-888

Kang S, Wanapat M (2013) Using plant source as a buffering agent to manipulating rumen fermentation in an in vitro gas production system. Asian-Australas J Anim Sci 26: 1424

Kmicikewycz AD, Heinrichs AJ (2014) Feeding lactating dairy cattle long hay separate from the total mixed ration can maintain dry matter intake during incidents of low rumen $\mathrm{pH}$. J Dairy Sci 97: 7175-7184

Mao S, Huo W, Liu J, Zhang R, Zhu W (2017) In- vitro effects of sodium bicarbonate buffer on rumen fermentation, levels of lipopolysaccharide and biogenic amine, and composition of rumen microbiota. J Sci Food Agric 97: 1276-1285

Marden JP, Julien C, Monteils, V, Auclair E, Moncoulon R, Bayourthe C (2008) How does live yeast differ from sodium bicarbonate to stabilize ruminal $\mathrm{pH}$ in high-yielding dairy cows?. J Dairy Sci 91: 3528-3535

Menke KH, Steingass H (1988) Estimation of the energetic feed value obtained from chemical analysis and gas production using rumen fluid. Anim Res Dev 28: 7-55

Morgante M, Stelletta C, Berzaghi P, Gianesella M, Andrighetto I (2007) Subacute rumen acidosis in lactating cows: an investigation in intensive Italian dairy herds. J Anim Physiol Anim Nutr 91: 226234

Owens FN, Basalan M (2016) Ruminal fermentation. In Rumenology:63102

Patra AK, Yu Z (2013) Effects of gas composition in headspace and bicarbonate concentrations in media on gas and methane production, degradability, and rumen fermentation using in vitro gas production techniques. J Dairy Sci 96: 4592-4600

Pereira MN, Armentano LE (2000) Partial replacement of forage with nonforage fiber sources in lactating cow diets. II. Digestion and rumen function. J Dairy Sci 83: 2876-2887

Springer Cham, Sen, AR, Santra A, Karim SA (2006) Effect of dietary sodium bicarbonate supplementation on carcass and meat quality of high concentrate fed lambs. Small Rumin Res 65: 122-127

Umucalilar HD, Seker E (2000) Effects of sodium bicarbonate and magnesium oxide as buffers on in vitro digestibility of grains. Veteriner Bilimleri Dergisi 16: 129-135

VanSoest PJ, Robertson, JB, Lewis BA (1991) Methods for dietary fiber, neutral detergent fiber, and non-starch polysaccharides in relation to animal nutrition. J Dairy Sci 74: 3583-3597

Xu S, Harrison JH, Riley RE, Loney KA (1994) Effect of buffer addition to high grain total mixed rations on rumen $\mathrm{pH}$, feed intake, milk production, and milk composition. J Dairy Sci 77: 782-788 